\title{
Erecting a Tombstone for 36 Million Famine Victims
}

Xu Youyu

\section{(2) OpenEdition \\ 1 Journals}

\section{Electronic version}

URL: http://journals.openedition.org/chinaperspectives/4783

DOI: 10.4000/chinaperspectives.4783

ISSN: 1996-4617

\section{Publisher}

Centre d'étude français sur la Chine contemporaine

\section{Printed version}

Date of publication: 1 April 2009

Number of pages: 98-101

ISSN: 2070-3449

\section{Electronic reference}

Xu Youyu, «Erecting a Tombstone for 36 Million Famine Victims », China Perspectives [Online], 2009/1 | 2009, Online since 01 April 2011, connection on 24 September 2020. URL : http:// journals.openedition.org/chinaperspectives/4783; DOI : https://doi.org/10.4000/chinaperspectives. 4783

(C) All rights reserved 
C

\title{
Erecting a Tombstone for
}

\section{Million Famine Victims}

\author{
XU YOUYU
}

Starting in the 1990s, the author of Tombstone, Yang Jisheng, began using his position as a Xinhua reporter to gather information on the Great Famine [of 1959-1961]. The resulting massive compendium of data and inside information provides details on the severity of the famine and its causes in each province, and powerfully refutes official prevarication over the disaster. (Kaifang)

A scholar and senior reporter with the Xinhua News Agency, Yang Jisheng garnered considerable interest in China and overseas when he published his book Tombstone: A Record of the Great Famine in China in the 1960s in Hong Kong in 2008. Although a number of books on the famine have been published in China and the West, Yang's book is notable for the comprehensiveness and accuracy of the information presented, the startling and previously unknown inside information he provides, his detailed and closely reasoned evidence, and the authority and credibility of his conclusions.

I feel this is a monumental work comparable to Solzhenitsyn's Nobel Prize-winning work The Gulag Archipelago. Although Chinese authors have exposed the truth behind the Chinese gulag to a large extent, if we say that Russia's Gulag symbolised the Stalinist era, the death of tens of millions of people in China's Great Famine must be considered similarly emblematic of the Mao Zedong era. I have previously lamented that the victims and survivors of China's repeated political movements have not benefited from a single-minded devotion to restoring history on the same scale as Solzhenitsyn's obsessively and tenaciously compiled record of evil. Tombstone embodies a conscience, sense of national responsibility, and historical insight similar to Solzhenitsyn's, and in its compilation and analysis of historical records and disclosure of inside information, it actually surpasses The Gulag Archipelago. Of course it can be said that Yang Jisheng's identity and circumstances were more conducive to the project than Solzhenitsyn's, but as a rule, advantages of position and circumstances can actually bring their own baggage and concerns. There have been others like Yang Jisheng who as insiders to the system have placed themselves at great personal risk for the sake of justice - Gu Zhun and Li Shenzhi ${ }^{(1)}$ come to mind - but they have been few and far between.

Part of the motivation behind Tombstone is deeply personal. The author's father, a good and upright ordinary peasant, starved to death during the famine in 1959, and half a century later, his father's miserable last days and the unbearable conditions in his home village remain stark before the author's eyes. In his preface, the author says that the book is his means of erecting a tombstone for his father and for the other 36 million victims of the famine.

\section{An authentic panoramic account of the famine}

Starting in the 1990s, the author used his position and opportunity to travel around the country as a Xinhua reporter to gain access to relevant documents and interview people who had experienced the famine. With the help of colleagues and friends, he was able to talk with former officials who were familiar with the situation, and also to read highly confidential files and documents. All of this helps make Tombstone a comprehensive and authentic record of the famine.

1. Gu Zhun (1915-1974) was a liberal intellectual who spent much of his later years in prison as a victim of anti-Rightist purges. Li Shenzhi (1923-2003) was vice-president of the Chinese Academy of Social Sciences and a noted proponent of liberalism. (All footnotes are Translator's Notes) 
When China's Great Famine is mentioned, the first place that comes to mind is Henan Province, especially the Xinyang area. Focusing on Xinyang, Tombstone provides detailed records that drill down to the county and village level, as well as examining the situation at the provincial level, in the Central South Bureau, and in the central government. After comparing and analysing the various data and methods, the author concludes that at least 3 million people starved to death in Henan Province, with 1 million dying in the Xinyang area alone, more than one out of every eight inhabitants.

The population of Gansu Province totalled only 13 million, but more than 1 million died of starvation throughout the province. The greatest proportion of deaths occurred in Tongwei County, where one out of every three inhabitants died and 70 percent of all families experienced at least one death, with some families completely wiped out. A cadre who was dispatched to sort out the "Tongwei problem" at the time recalls seeing the dead and the living lying together on beds, along the roadways, and in the fields, the living lacking the strength or will to bury the dead; in any case, it was the living they feared, not the dead, because the living might well eat them.

Sichuan had throughout China's history enjoyed the reputation of "Heaven's pantry," thanks to its fertile soil and abundant crops, but it suffered the most deaths of any other province during the famine, a total of some 10 to 12 million. The difficulty in ascertaining the exact number is due to the fact that at that time the Sichuan Provincial Party Committee had political control over population statistics, and ordered that the areas reporting the highest number of deaths "carry out a new survey." Sichuan suffered from the famine for the longest period of time. Its top leader, $\mathrm{Li}$ Jingquan, ${ }^{(2)}$ was adept at anticipating Mao Zedong's wishes. He did not flinch from proceeding with the ultra-leftist Great Leap Forward, and sent out vast quantities of the province's produce as a testimony to the correctness of official policy and the favourability of the province's circumstances. He paved his eventual promotion to the Politburo with 10 million lives.

Anhui's Fengyang County became renowned for the number of its inhabitants that fled in search of food. Out of the county's original 400,000 residents, some 90,000 starved to death during the three years of famine, nearly one out of every four. The main cause of the famine was high production targets and yield estimates coupled with high rates of procurement. Fengyang's production target in 1958 was 400 million kilos of grain, ${ }^{(3)}$ but the actual harvest was only 80 million kilos. The state forcibly requisitioned 43 percent of the harvest, leaving the farmers who had produced it without enough grain to meet their own needs. In 1959, the county produced 90 million kilos, compared with its target of 200 million. An estimated 5 to 6 million people starved to death in Anhui Province, more than 15 percent of the total population. In Hao County there were recurrent incidents of cannibalism, and even reports of human flesh being sold from stalls and carts that circulated from village to village. Many of the incidents that occurred during the famine years seem fantastic when viewed from today's perspective, and would seem laughable if they were not so tragic. In the spring of 1960, villages in the Dingxi region of Gansu Province ran out of food, but the local Party secretary said, "It's better for people to starve to death than for us to ask the state for food supplies." In the process of forcibly requisitioning foodstuffs, Tongwei County sent the following directive to the People's Communes: "If you cannot fulfil the food requisitioning assignment, bring your heads on a platter!" The slogan at the time was, "Better to owe a blood debt than a food debt. Fulfilling the grain assignment is a fight to the death." In the winter of 1960, the Party committee of Hebei Province decided that each villager should be allocated a grain ration of four liang a day (the equivalent of about 125 grams in today's measurement). The head of the Party committee said that eating four liang was Marxist, and eating more than that was anti-Marxist. Subsequently the committee put forward the slogan, "Eat four liang and bask in the sun." Tombstone's author notes that a person cannot perform photosynthesis, so how could sunbathing make up for lack of sustenance?

\section{Total starvation toll and the causes of the famine}

How many people actually died in the course of the Great Famine? This is a question that has raised strong debate and a variety of opinions.

Before Tombstone's publication, researchers in China and abroad had compiled various data and materials in an attempt to calculate how many people had died, with most estimates ranging from 20 to 40 million. Old guard and neo-

2. Li Jingquan (1908-1989), a key figure in China's southwest region in the 1950s and 1960 s, was attacked during the Cultural Revolution as a "governor of his own kingdom" and relieved of all his positions, but he was rehabilitated in 1973, serving on the CСР Central Committee and the Standing Committee of the National People's Congress until a few years before his death.

3. Literally, 800 million $j i n$, a Chinese measure of volume equivalent to about half a kilogram. Subsequent measures have been similarly converted. 
leftists wracked their brains to undermine these estimates, arguing without the backing of evidence that they had been purposely exaggerated in order to slander the reputations of Mao Zedong, the Great Leap Forward, and the People's Communes. Their quibbles assumed a cruel logic under which starvation deaths below a certain number should be considered normal and acceptable and proof that Mao had not been wrong. In fact, taking a mere 10 percent of the lowest estimate, we can go back to these leftists and ask what justification there might be for even two million people to have starved to death.

Yang Jisheng's conclusion after comparing and analysing various methods and figures is that the number of people throughout China who died unnatural deaths during the Great Famine totalled 36 million, with an estimated additional 40 million who were never born as a result of the famine, making a total loss to China's population of 70 million lives. I believe this is a relatively scientific and reliable figure.

What caused this nationwide famine, and why did it kill so many people? From Tombstone we learn of the following causes.

Because of the exaggerations of the Great Leap Forward, all provinces and localities raised their production targets, yield estimates, and procurement levels. China's total grain output was stated as 375 billion kilos in 1958, but the subsequently recorded figure (itself quite possibly an exaggeration) was 200 billion kilos. The actual production output was about the same as the year before, but government procurement increased by 20 percent, with the result that food was virtually snatched from the mouths of the peasants.

In order to meet the high procurement quotas, peasants were forced to throw in their grain rations, livestock feed, and seeds, and if the procurement quota still wasn't met, the higher level authorities accused the peasants of falsely reporting output and holding back a portion for themselves (manchan sifen). It was standard practice throughout the country to use methods such as dismissing grassroots cadres, holding public criticism sessions, beatings, re-education through labour, and detention to force households to surrender grain, and countless local cadres and peasants were harshly beaten, some of them to death. Public criticism sessions employed the following catechism: "Has the production team made a Great Leap Forward?" "We have leaped forward." "Are the People's Communes outstanding?" "They're outstanding." "So why don't you hand over your grain?"

Other slogans included, "Hiding grain is like concealing a bomb." The famous scientist Qian Xuesen ${ }^{(4)}$ published an article confirming that crop yields could attain 19,500 kilos per $m u^{(5)}$ of land, providing "scientific proof" for the cam- paign against "false reporting of output and holding back for personal use."

The communal kitchens that Mao Zedong so loved and promoted were a major cause of starvation among the peasants. Based on his analysis of the data, the author holds that without communal kitchens, the number of deaths might have been reduced by a third and in some places by half. Promotion of the communal kitchens resulted in free meals for the first two months, during which people ate and drank to their hearts' content, followed by a battle with famine when food ran out. That involved forcing peasants to contribute to the program, combining all food resources, confiscating cooking utensils, detaining householders who built their own hearth fires, and stripping peasant homes to their timbers. The greatest damage caused by the communal kitchens was "imposing the dictatorship of the proletariat on each individual's stomach." Cadres exerted full power over who was allowed or not allowed to eat, while assuming a position in which they had the privilege of eating all they wanted.

The abuse of power by officials and cadres exacerbated the distress of already desperate peasants. Militia were dispatched to surround, pursue, intercept, cut off, and detain peasants to prevent them from seeking refuge elsewhere, depriving famine victims of their last chance for survival.

\section{Denouncing the sophistry and lies of Party officials}

Facing this monumental tragedy, the Party leadership fabricated sources of blame such as a "three-year natural disaster" and "indebtedness to the Soviet revisionists," platitudes that continued to trip off the tongues of the Chinese people for many years. Tombstone includes a detailed examination and powerful refutation of these allegations.

The author cites authoritative climatic data and the views of authoritative climate experts to show that weather and climate conditions were unexceptional in the years 1959-1961. That is to say, given the vastness of China's land mass, it would be difficult to avoid some form of natural calamity in the course of a year, but those occurring in the three years of the famine were no more severe than in other years. The author goes a step further to point out that historical data show little direct relationship between crop yield and natural disasters; the 11 years of 1956, 1957, 1962, 1963, and 19771983 all experienced natural disasters on a wider scale than

\footnotetext{
4. Born in 1911, Qian received PhDs from MIT and the California Institute of Technology before returning to China and gaining renown as the "Father of Chinese Aerospace."
}

5. Approximately 0.66 square kilometres. 
in 1959, but no famine resulted, and in 9 of those years, crop yield actually exceeded that of the year before.

The accusation against the USSR was that the Soviets tore up agreements, withdrew expert advisors and began pressing China for repayment of debts. Tombstone points out that the USSR's cancelling of agreements and withdrawal of expert advisors occurred in the second half of 1960, when the Great Famine had already been in progress for more than a year, and in any case, the expert advice and science and technology agreements were not related to agriculture or crop yield. As far as the repayment of debt is concerned, the author could not find a single document or piece of data to back up the allegation. On the contrary, in March 1961 the Soviet Union suggested that in order to help China deal with the famine, it was willing to loan China one million tons of wheat and 500,000 tons of cane sugar. China, however, refused the wheat and only accepted the sugar. China paid off its debt to the Soviet Union before it came due, but this was not because of pressure from the USSR, but rather Mao Zedong taking the initiative to "vindicate" himself in the eyes of Soviet leaders.

The book quotes China's Foreign Trade Minister as saying in 1961, "Because of the severe natural disaster suffered by China over the last two years, there was a very large shortfall in the commodities provided to the Soviet Union in 1960. In 1961 there were many products that could not be exported or could only be exported in smaller quantities, which caused definite hardship for the Soviet Union. However, our Soviet comrades expressed a comradely cooperation and fraternal understanding regarding this situation. The Soviet government agreed to let us repay our trade debt in instalments over the next five years without interest. They also offered to loan China 500,000 tons of cane sugar on an interest-free basis, which China could subsequently repay in the same quantity. We feel this is a great help and support to us in surmounting our temporary difficulties." (6)

During the famine years, the Chinese government provided enormous funding and material aid to certain countries, some of which already enjoyed a much higher standard of living than China. While China's peasants were dropping like flies from starvation, the government continued to export large quantities of foodstuffs. China experienced reduced food output in 1959 compared with 1957, but its food exports doubled to a record high. That amount of food would have been enough to feed 24.5 million people for an entire year.

In 1960, while vast numbers of peasants were starving to death, the authorities would not consider opening the grain stores, but rather added to their stock. In a year when death by starvation reached a peak, the state held tens of billions of kilos of grain in storage.

The leftists defend the government by saying that the famine was caused by the reckless actions of lower-level cadres, and that the central government and Mao himself knew nothing of the true circumstances. On this point the book makes its most important disclosure: In 1961, the heads of the Food Ministry and the State Bureau of Statistics were ordered to fill out a form detailing food supplies and population for each province of China. Their figures showed that the country's population had been reduced by tens of millions. This data was provided exclusively to Zhou Enlai and Mao Zedong, and after reviewing it, Zhou ordered that it be immediately destroyed and not shown to anyone else. Subsequently Zhou chased up the matter to ascertain that the data had in fact been destroyed, and was only able to relax upon being reassured on that point.

When Mao Zedong was informed of the severity of the situation in Xinyang, he attributed the matter to class enemies usurping leadership, a restoration to power of the counterrevolutionaries, and a frenzied class retaliation inflicted upon the working people. He resolved this by carrying out supplementary training in democratic revolution, which brought about wide-scale infighting, dismissals, and detentions among grass-roots cadres.

Another excuse advanced by some is that Mao Zedong suffered along with the rest of the Chinese people during the three years of hardship, and ate no meat. The book refutes this by citing official publications, including the menu for a Western-style meal for Mao that included fish and prawns prepared in 17 different styles. An inside source also reveals that a doctor warned Mao of an elevated cholesterol count caused by excessive pork consumption, and advised him to switch to mutton. During that period, villas and guest houses were being constructed and refurbished throughout China to house Mao to a standard of luxury exceeding that of state guest houses.

Tombstone analyses the systemic factors involved in the Great Famine, with the author throughout the book describing this system as "totalitarianism." This shows that the author's understanding is on a par with the importance of the subject. $\bullet$

\section{- This article was published in the October 2008 edition of Hong Kong's Open Magazine (Kaifang).}

\section{- Translated by Stacy Mosher}

6. See "The Expensive Mr. Mao," contemporary media analyses on the 1961 USSR-China trade protocol, posted on the Open Society Archives, http://www.osaarchivum.org/ files/holdings/300/8/3/text/90-4-183.shtml. 